Jurnal Semarak,Vol. 3,No.1, Februari 2020, Hal (41- 51)

@ Prodi Manajemen Fakultas Ekonomi Universitas Pamulang

\title{
PENGARUH CAPITAL ADEQUACY RATIO (CAR) DAN NON PERFORMING \\ LOAN(NPL) TERHADAP PROFITABILITAS (ROA) \\ PT BANK RAKYAT INDONESIA Tbk. \\ (Periode 2008 - 2016)
}

Amthy Suraya, Sri Malani

Dosen Fakultas Ekonomi Universitas Pamulang

Email: dosen00627@unpam.ac.id

\begin{abstract}
ABSTRAK
Penelitian ini bertujuan untuk mengetahui pengaruh Capital Adequacy Ratio dan Non Performing Loan Terhadap Profitabilitas (ROA) pada PT Bank Rakyat Indonesia Tbk. Data yang digunakan dalam penelitian ini adalah data sekunder yang bersumber dari data keuangan PT Bank Rakyat Indonesia Tbk. yang telah dipublikasikan melalui www.ir-bri.com, www.bri.co.id, serta www.idx.co.id. Variabel independen yang diuji dalam penelitian ini yaitu Capital Adequacy Ratio (CAR) dan Non Performing Loan (NPL). Sedangkan variabel dependen yang digunakan adalah Return On Asset (ROA). Dalam penelitian ini menggunakan 9 sampel data dari laporan keuangan dan laporan rasio kinerja keuangan periode 2008 - 2016.

Metode penelitian ini bersifat deskriptif dengan menggunakan pendekatan kuantitatif. Metode ini mengemukakan kondisi perusahaan berdasarkan data rill yang dikumpulkan dari berbagai sumber, data yang diperoleh diolah dan dianalisis sehingga memperoleh gambaran secara sistematik dan dapat ditarik kesimpulan.

Berdasarkan pengujian statistik diketahui bahwa seluruh data pengujian asumsi klasik yaitu, data terdistribusi normal, tidak terjadi multikolinearitas, tidak terjadi heteroskedastisitas, dan tidak terjadi autokorelasi. Hasil analisis regresi linier sederhana CAR diperoleh persamaan $\mathbf{Y}=\mathbf{4 , 8 4 2}+\mathbf{- 0 , 0 2 1} \mathbf{X}$ negatif dan tidak berpengaruh signifikan terhadap ROA dan untuk NPL diperloeh persamaan $\mathbf{Y}=\mathbf{5 , 4 4 3}+\mathbf{- 1 , 4 9 9}$ Xnegatif dan berpengaruh signifikan terhadap ROA. Hasil analisis regresi linier berganda diperoleh persamaan $\mathbf{5 , 9 3 6}+\mathbf{- 0 , 0 2 9}\left(\mathbf{X}_{1}\right)+\mathbf{- 1 , 5 1 6}\left(\mathbf{X}_{2}\right)$ keduanya bernilai negatif dan berpengaruh signifikan secara simultan terhadap ROA.Hasil uji tuntuk CAR $\mathrm{t}_{\text {hitung }}=-1,159 \mathrm{t}_{\text {tabel }} 2,446 \mathrm{t}_{\text {hitung }}<\mathrm{t}_{\text {tabel }}$ dengan nilai signifikansi $0,291>0,05$ artinya tidak berpengaruh secara parsial terhadap profitabilitas (ROA). Hasil uji tuntuk $N P L t_{\text {hitung }}=-5,640$ sedangkan $t_{\text {tabel }} 2,446 t_{\text {hitung }}>t_{\text {tabel }}$ dengan nilai signifikansi $0,001<$ 0,05artinya berpengaruh secara parsial terhadap profitabilitas (ROA). Untuk uji $\mathrm{F}$ diperoleh $F_{\text {hitung }}$ adalah 16,529 dan $F_{\text {tabel }} 5,14 F_{\text {hitung }}>F_{\text {tabel }}$ dengan nilai signifikansi 0,004 $<0,05$ artinya CAR dan NPL berpengaruh secara simultan (bersama-sama) terhadapprofitabilitas (ROA).
\end{abstract}

Kata kunci: Capital Adequacy Ratio (CAR) dan Non Performing Loan (NPL) Terhadap Profitabilitas (ROA). 


\section{PENDAHULUAN}

\section{A. Latar Belakang}

Perekonomian Indonesia seiring berjalannya waktu terus mengalami peningkatan. Hal ini didukung oleh berbagai sektor perekonomian yang ada di Indonesia, salah satunya adalah sektor perbankan. Peningkatan perekonomian sangat didukung oleh sektor perbankan yang ditunjukkan dengan peningkatan dana yang mampu diserap dan kemudian disalurkan kembali kepada masyarakat dalam bentuk kredit.

Tujuan akhir sebuah perusahaan termasuk perbankan dalam mengelola usahanya adalah memperoleh keuntungan atau profit. Dengan memperoleh laba maksimal yang telah diharapkan dapat mempengaruhi peningkatan kesejahteraan karyawan dan pemilik termasuk yang paling penting adalah meningkatkan perekonomian nasional.

Menurut Kasmir (2012:196), mengatakan bahwa "Rasio profitabilitas merupakan rasio untuk menilai kemampuan perusahaan dalam mencari keuntungan. Rasio ini juga memberikan ukuran tingkat efektifitas manajemen suatu perusahaan.". Dalam rasio profitabilitas memuat perbandingan antara komponen-komponen yang ada pada laporan keuangan, dari hasil yang diperoleh dapat dijadikan sebagai bahan evaluasi kinerja manajemen dalam kurun waktu tertentu.

Variabel-variabel yang digunakan untuk mengukur tingkat profitabilitas bank adalah sebagai berikut :

1. Capital Adequacy Ratio (CAR)

Menurut Kasmir (2014:46), CAR adalah perbandingan rasio tersebut antara rasio modal terhadap Aktiva Tertimbang Menurut Resiko dan sesuai ketentuan pemerintah. Sedangkan Menurut Bank Indonesia (Nomor 9/13/PBI/2007), CAR adalah penyediaan modal minimum bagi bank didasarkan pada risiko aktiva dalam arti luas, baik aktiva yang tercantum dalam neraca maupun aktiva yang bersifat administratif sebagaimana tercermin pada kewajiban yang masih bersifat kontijen dan/atau komitmen yang disediakan oleh bank bagi pihak ketiga maupun risiko pasar. CAR diukur dengan membagi modal dengan aktiva tertimbang menurut resiko (ATMR).

Maka dapat disimpulkan bahwa semakin tinggi tingkat presentase CAR maka akan semakin memperkuat kemampuan yang dimiliki oleh bank untuk menanggung segala resiko kredit atau aktiva produktif yang sangat beresiko. Menurut Bank Indonesia tingkat CAR minimum untuk bank adalah $8 \%$, 
2. Non Performing Loan (NPL)

Penyaluran kredit dari bank kepada masyarakat memiliki banyak resiko, terutama resiko kredit yaitu ketidakmampuan debitur untuk membayar kewajibannya sehingga dapat menghasilkan kredit bermasalah.

NPL merupakan tingkat kredit yang tidak dapat dibayarkan dalam kurun waktu lebih dari 3 bulan (90 hari). Kategori NPL yaitu Kurang Lancar, Diragukan, dan Macet. Batas aman dari NPL suatu bank tidak boleh melebihi 5\% dari total kredit atau aktiva produktif.

Semakin rendah tingkat NPL pada sebuah bank maka akan sangat mempengaruhi peningkatan keuntungan bank, dan sebaliknya apabila tingkat NPL bank dinyatakan tinggi maka dapat terus merugikan bank.

Dari uraian diatas, maka penulis sangat tertarik untuk memilih judul "Pengaruh Capital Adequacy Ratio (CAR)dan Non Performing Loan (NPL)terhadap Profitabiltas (ROA) PT Bank Rakyat Indonesia Tbk." sebagai judul dari skripsi penulis, karena dengan tingkat Capital Adequacy Ratio (CAR) dan Non Performing Loan (NPL) bank dapat mengukur tingkat profit atau keuntungan yang didapatkan.

\section{B. Indentifikasi Masalah}

$$
\begin{aligned}
& \text { Berdasarkan latar belakang } \\
& \text { diatas, penulis } \\
& \text { mengidentifikasikan masalah pada } \\
& \text { penelitian ini, yaitu: } \\
& \begin{array}{l}
\text { 1. Kurangnya modal dapat } \\
\text { mempengaruhi kemampuan PT }
\end{array}
\end{aligned}
$$

\author{
BANK RAKYAT INDONESIA \\ Tbk. untuk menutup resiko \\ kerugian dan ketidakmampuan \\ dalam mendanai kegiatan \\ operasionalnya.
}

2. Tingginya tingkat kredit macet dapat mempengaruhi keuntungan PT BANK RAKYAT INDONESIA Tbk.

3. Lending yang tidak tepat dan tidak maksimal akan mempengaruhi pendapatan bank dari margin kredit dan akan berpengaruh pada tingkat keuntungan bank.

4. Kondisi internal bank yang lemah dapat menurunkan tingkat kinerja keuangan bank.

5. Tingkat kinerja keuangan yang tidak cukup baik akan mempengaruhi tingkat keuntungan bank.

\section{Pembatasan Masalah}

Berdasarkan identifikasi
masalah diatas dan mengingat
cakupan masalah yang luas dalam
pembahasan ini, maka penulis
membatasi permasalahan yang akan
dibahas, yaitu:

1. Menurut Kasmir (2014:46) Capital Adequacy Ratio (CAR) adalah perbandingan rasio tersebut antara rasio modal terhadap Aktiva Tertimbang Menurut Resiko dan sesuai ketentuan pemerintah.

2. Menurut Kasmir (2013:155) Non Performing Loan (NPL) adalah kredit yang didalamnya terdapat hambatan yang disebabkan oleh 2 unsur yakni dari pihak perbankan dalam menganalisis maupun dari pihak nasabah yang sengaja atau 
tidak sengaja dalam kewajibannya tidak melakukan pembayaran.

3. Menurut Kasmir (2014:201) "Return On Asset (ROA) merupakan rasio yang menunjukkan hasil atas jumlah aktiva yang digunakan dalam perusahaan."

4. Penelitian ini dilakukan pada PT BANK RAKYAT INDONESIA Tbk. dengan berdasarkan data sekunder yang diambil dari data perusahaan yang sudah dipublikasikan.

\section{RumusanMasalah}

Berdasarkan latar belakang, identifikasi masalah, serta pembatasan masalah yang telah diuraikan diatas, maka dapat dibahas perumusan masalah sebagai berikut :

1. Bagaimana pengaruh Capital Adequacy Ratio (CAR) terhadap terhadap profitabilitas (ROA) pada PT BANK RAKYAT INDONESIA Tbk. Dari tahun 2008 sampai dengan 2016 ?

2. Bagaimana pengaruh Non Performing Loan (NPL) terhadap profitabilitas (ROA) pada PT BANK RAKYAT INDONESIA Tbk. Dari tahun 2008 sampai dengan 2016 ?

3. Bagaimana pengaruh Capital Adequacy Ratio (CAR) dan Non Performing Loan (NPL) terhadap terhadap profitabilitas (ROA) pada PT BANK RAKYAT INDONESIA Tbk. Dari tahun 2008 sampai dengan 2016 ?

\section{E. Tujuan dan Manfaat}

Tujuan Penelitian

a. Untuk mengetahui bagaimana pengaruh Capital Adequacy Ratio
(CAR) terhadap terhadap profitabilitas (ROA) pada PT BANK RAKYAT INDONESIA Tbk.

b. Untuk mengetahui bagaimana pengaruh Non Performing Loan (NPL) terhadap terhadap profitabilitas (ROA) pada PT BANK RAKYAT INDONESIA Tbk.

c. Untuk mengetahui apakah terdapat pengaruh Capital Adequacy Ratio (CAR) dan Non Performing Loan (NPL) terhadap profitabilitas (ROA) pada PT BANK RAKYAT INDONESIA Tbk.

Manfaat Penelitian

Jika tercapainya tujuan yang diharapkan maka akan diperoleh manfaat sebagai berikut :

a. Sebagai bahan masukan dan bahan pertimbangan dalam pengambilan keputusan yang berhubungan dengan pencapaian tingkat keuntungan.

b. Sebagai penambah literature dan referernsi bahan bacaan.

c. Sebagai sarana penerapan ilmu pengetahuan yang didapatkan dari kegiatan perkuliahan, sehingga dapat menambah wawasan dan pengetahuan secara teori dan praktik.

\section{TINJAUAN PUSTAKA}

\section{A. Manajemen}

Menurut Hasibuan (2012:1) manajemen adalah seni atau suatu kreatifitas pribadi yang kuat dan disertai keterampilan. Sedangkan menurut Hari Sucahyowati (2017:5) manajemen adalah proses yang terdiri dari rangkaian kegiatan 
seperti planing, organizing, staffing, directing dan controling yang dilakukan oleh para anggota organisasi dan menggunakan seluruh sumberdaya organisasi untuk menentukan dan mencapai tujuan yang telah ditetapkan. Dari pengertian diatas penulis dapat menyimpulkan secara sederhana bahwa manajemen merupakan proses pencapaian tujuan perusahaan atau organisasi dengan mengandalkan sumberdaya yang dimiliki oleh perusahaan dengan dimulai dari perencanaan, pengorganisasian, pelaksanaan dan pengawasan.

\section{B. Manajemen Keuangan}

Menurut Kasmir (2010: 5) adalah "segala aktivitas yang berhubungan dengan pengelola, pendanaan,dan pengelola aktiva dengan beberapa tujuan menyeluruh." Berdasarkan pengertian tersebut maka dapat disimpulkan bahwa manajemen keuangan adalah aktivitas dalam sebuah perusahaan untuk memperoleh dana dan mengelola dana tersebut dalam berbagai kegiatan untuk menunjang aktivitas perusahaan dan mencapai tujuan perusahaan.

\section{Bank}

Menurut Undang Undang Republik Indonesia No. 10 Tahun 1998 tanggal 10 November 1998 tentang perbankan, yang dimaksud dengan bank adalah badan usaha yang menghimpun dana dari masyarakat dalam bentuk simpanan dan menyalurkan ke masyarakat dalam bentuk kredit atau bentuk-bentuk lainnya dalam rangka meningkatkan taraf hidup rakyat banyak. Menurut
Kasmir (2014: 14) "Bank adalah badan usaha yang menghimpun dana dari masyarakat dalam bentuk simpanan dan menyalurkannya." Dari pengertian tersebut dapat disimpulkan bahwa bank merupakan lembaga keuangan yang memiliki wewenang untuk mengimpun dana masyarakat dan menyalurkannya dalam bentuk kredit untuk masyarakat serta memberikan jasa jasa lainnya dengan tujuan untuk meningkatkan kesejahteraan masyarakat.

\section{Laporan Keuangan}

Laporan keuangan menurut Kasmir (2012:280) merupakan suatu hasil akhir dari pencatatan, yang merupakan suatu rangkaian dari transaksi keuangan yang terjadi selama tahun buku perusahaan yang bersangkutan. Jadi dapat disimpulkan bahwa laporan keuangan adalah pencapaian hasil kinerja perusahaan dalam satu periode akuntansi yang dituangkan dalam bentuk angka dan tulisan yang bersumber dari aktivitas perusahaan yang bertujuan untuk dasar pengambilan keputusan.

\section{E. Capital Adequacy Ratio (CAR)}

Menurut Kasmir (2014:46), "Capital Adequacy Ratio (CAR) adalah perbandingan rasio tersebut antara rasio modal terhadap Aktiva Tertimbang Menurut Resiko dan sesuai ketentuan pemerintah."

CAR memperlihatkan seberapa jauh seluruh aktiva bank yang mengandung resiko (kredit, penyertaan, surat berharga, tagihan pada bank lain) ikut dibiayai dari dana modal sendiri bank disamping memperoleh dana-dana dari sumber- 
sumber di luar bank, seperti dana masyarakat, pinjaman (utang), dan lain-lain (Pratiwi, 2016: 47). Rasio ini dapat dirumuskan sebagai berikut :

$$
\text { CAR }=\frac{\text { Modal Bank }}{\text { ATMR }} \times 100 \%
$$

\section{F. Non Performing Loan (NPL)}

$$
\begin{aligned}
& \text { Pengembangan ekonomi } \\
& \text { didukung oleh pelaku usaha } \\
& \text { individual maupun lembaga yang } \\
& \text { sebagian modalnya berasal dari bank } \\
& \text { berupa kredit atau pinjaman. } \\
& \text { Penyaluran kredit yang diberikan } \\
& \text { bank kepada nasabah dalam jumlah } \\
& \text { tertentu pasti sudah diperhitungkan } \\
& \text { pendapatannya yang akan diperoleh } \\
& \text { dari bunga dan tergantung pada } \\
& \text { kualitas pengembalian } \\
& \text { kredit. Menurut Kasmir (2013:155) } \\
& \text { Non Performing Loan (NPL) adalah } \\
& \text { kredit yang didalamnya terdapat } \\
& \text { hambatan yang disebabkan oleh } 2 \\
& \text { unsur yakni dari pihak perbankan } \\
& \text { dalam menganalisis maupun dari } \\
& \text { pihak nasabah yang sengaja atau tidak } \\
& \text { sengaja dalam kewajibannya tidak } \\
& \text { melakukan pembayaran. Rasio ini } \\
& \text { dapat dirumuskan sebagai berikut: }
\end{aligned}
$$

$$
\mathrm{NPL}=\frac{\text { Kredit }}{\text { Bermasalah }} \times 100
$$

\section{G. Return On Assets (ROA)}

Menurut Kasmir (2014:201) "Return On Assets (ROA) merupakan rasio yang menunjukkan hasil atas jumlah aktiva yang digunakan dalam perusahaan." Jadi dapat disimpulkan bahwa Return On Assets (ROA) merupakan rasio yang digunakan untuk mengukur kemampuan perusahaan dalam memperoleh keuntungan dari pengelolaan asset perusahaan. Semakin besar Return On Assets (ROA) maka akan semakin baik dan efektif asset yang digunakan oleh perusahaan untuk memperoleh keuntungan. Berdasarkan ketentuan Bank Indonesia standar nilai Return On Assets (ROA) minimal sebesar 1,5\%. Return On Assets (ROA) dapat diformulasikan sebagai berikut :

$$
\begin{aligned}
& \text { Return } \\
& \text { On } \\
& \text { Asset }
\end{aligned}=\frac{\begin{array}{c}
\text { Laba Bersih } \\
\text { Sebelum } \\
\text { Pajak }
\end{array}}{\text { Total Aset }} \times 100 \%
$$

\section{METODOLOGI PENELITIAN}

Dalam penelitian ini, jenis penelitian yang digunakan adalah penelitian kuantitatif dimana dalam penelitian kuantitatif dapat menggunakan pendekatan kuantitatif yang berdasarkan pada data hitung atau angka-angka yang berhubungan dengan permasalahan yang diteliti untuk menghasilkan sebuah keputusan.

\section{A. Waktu \& Tempat Penelitian}

Penelitian ini dilaksanakan mulai dari bulan Januari sampai dengan Juli 2018 berupa data keuangan PT Bank Rakyat Indonesia Tbk. Periode 2008 - 2016 yang sudah dipublikasikan. Data yang digunakan dalam penelitian ini adalah data sekunder yang bersumber dari data keuangan PT Bank Rakyat Indonesia Tbk. yang telah dipublikasikan melalui www.ir-bri.com, www.bri.co.id, serta www.idx.co.id.

\section{B. Jenis dan Objek Penelitian}

Menurut Sugiyono (2013:32) “objek penelitian adalah suatu atribut 
atau sifat atau nilai dari orang, objek atau kegiatan yang mempunyai variabel tertentu yang ditetapkan untuk dipelajari dan ditarik kesimpulan."hal ini yang menjadi objek penelitian sebagai variabel bebas (independent variable) adalah Capital Adequacy Ratio (CAR) dan Non Performing Loan (NPL) sedangkan variabel terikat (dependen variable) adalah Profitabilitas (ROA).

\section{Populasi dan Sampel}

Menurut Sugiyono (2011:80) Populasi adalah wilayah generalisasi yang terdiri atas objek/subjek yang mempunyai kualitas dan karakteristik tertentu yang ditetapkan oleh peneliti untuk dipelajari dan kemudian ditarik kesimpulannya.

Populasi yang dipilih dalam penelitian ini adalah keseluruhan laporan keuangan PT Bank Rakyat Indonesia Tbk. Periode 2008-2016.

Sampel menurut Sugiyono (2010:81) adalah "bagian dari jumlah dan karakteristik yang dimiliki oleh populasi tersebut." Teknik penarikan sampel yang digunakan dalam penelitian ini adalah purposive sampling atau bisa dikatakan sebagai pengambilan sampel non probability dimana sampel yang diambil dari sebuah populasi tidak memiliki peluang atau kesempatan yang sama serta memiliki syarat dan kriteria tertentu. Sampel yang digunakan dalam penelitian ini adalah laporan keuangan berupa laporan neraca, laba rugi dan laporan rasio kinerja keuangan PT Bank Rakyat Indonesia Tbk. periode 2008-2016.

\section{Metode Pengumpulan Data}

Metode pengumpulan data yang digunakan untuk memperoleh data yang bersumber dari data sekunder PT Bank Rakyat Indonesia Tbk. periode 2008 - 2016 yang sudah dipublikasikan.

\section{E. Metode Analisis Data}

Analisis deskriptif merupakan analisis yang berguna untuk menggambarkan besar kecilnya tingkat variabel (independen dan dependen) dalam tahun penelitian (Handayani 2014:49).

\section{F. Pengujian Asumsi Klasik}

Data yang digunakan dalam penelitian ini adalah data sekunder, oleh sebab itu untuk menentukan model regresi yang dapat dipertanggungjawabkan maka digunakan uji asumsi klasik. Adapun pengujian asumsi klasik yang digunakan dalam penelitian ini diantaranya Uji Normalitas, Uji multikolinieritas, Uji heteroskedastisitas, Uji autokorelasi.

\section{G. Analisis Regresi Linier Sederhana}

Menurut Sugiyono (2012:270) "analisis regresi linier sederhana digunakan untuk memprediksikan seberapa jauh hubungan fungsional ataupun kausal satu variabel independen dengan satu variabel dependen." Analisis Regresi Linier Sederhana dapat diformulasikan sebagai berikut :

$$
\mathrm{Y}=\mathrm{a}+\mathrm{bx}
$$

\section{H. Analisis Regresi Linier Berganda}

$$
\text { Menurut Sugiyono }
$$

(2010:277) adalah analisis yang 
digunakan peneliti, bila bermaksud meramalkan bagaimana keadaan (naik turunnya) variabel dependen (kriterium), bila dua atau lebih variabel independen sebagai faktor prediktor dimanipulasi (dinaik turunkan nilainya). Analisis regresi linier berganda dapat diformulasikan sebagai berikut :

$$
\mathrm{Y}=\alpha+\beta_{1} \mathrm{X}_{1}+\beta_{2} \mathrm{X}_{2}+\mathrm{e}
$$

\section{Pengujian Signifikansi}

Dalam sebuah penelitian, tingkat signifikansi umumnya dipilih sebesar 0,05 atau $5 \%$ karena memungkinkan hasil penarikan kesimpulan mempunyai probabilitas $95 \%$ atau dengan toleransi kesalahan sebesar 5\%. Untuk menguji hipotesis diterima atau ditolak dapat menggunakan pengujian Uji signifikan parsial (uji t) dan Uji Signifikansi Simultan (Uji f).

\section{J. Analisis Koefisien Determinasi $\left(\mathbf{R}^{\mathbf{2}}\right)$} Menurut Ghozali (2013:97) koefisien determinasi $\left(\mathrm{R}^{2}\right)$ bertujuan untuk mengukur seberapa jauh kemampuan model dalam menerangkan variasi variabel dependen.

\section{HASIL PENELITIAN DAN PEMBAHASAN}

\section{A. Hasil Analisis Statistik Deskriptif}

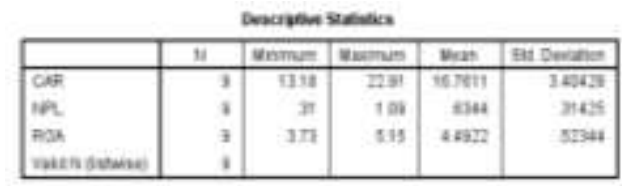

\section{B. Hasil Uji Asumsi Klasik}

Uji Normalitas

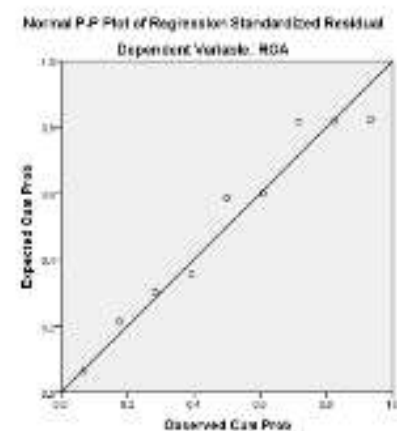

Uji Multikolinieritas

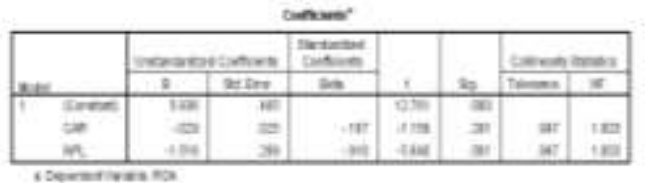

Uji Heteroskedastisitas

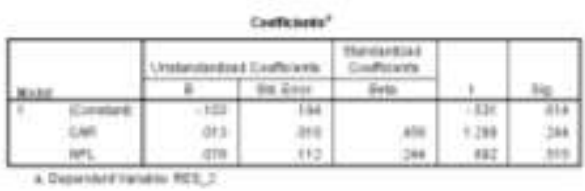

Uji Autokorelasi
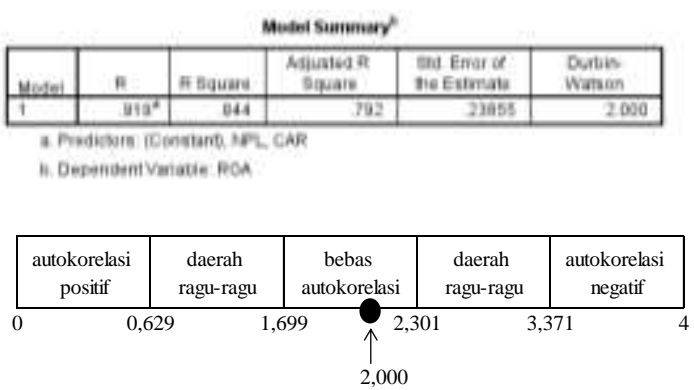

\section{Analisis Regresi Linier Sederhana} CAR
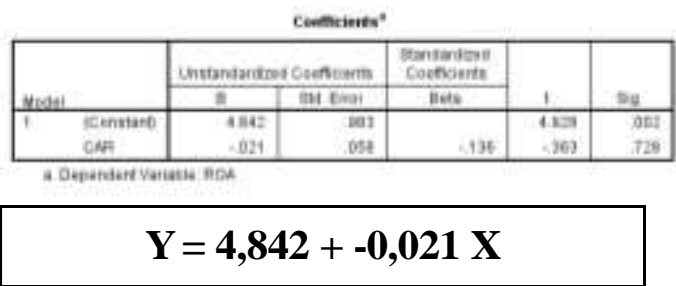

\section{NPL}

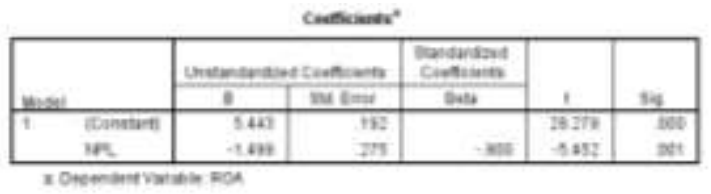




$$
Y=5,443+-1,499 X
$$

\section{Analisis Regresi Linier Berganda}

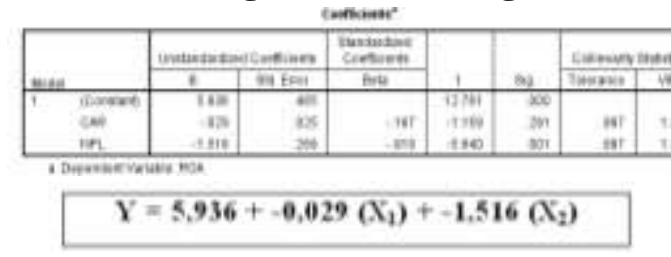

E. Uji Signifikansi

Uji Signifikan Parsial (uji t)

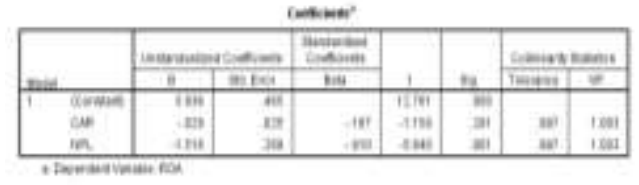

Hasil uji signifikansi parsial (uji t) dapat disimpulkan sebagai berikut :

a. Variabel Capital Adequacy Ratio (CAR) sebagai variabel independen menunjukkan hasil statistik uji signifikansi parsial uji $\mathrm{t}_{\text {hitung }}=-1,159$ sedangkan $t_{\text {tabel }} 2,446 \quad t_{\text {hitung }}<t_{\text {tabel }}$ dengan nilai signifikansi $0,291>0,05$. Maka dapat diketahui bahwa $\mathrm{Ho}_{1}$ diterima dan $\mathrm{Ha}_{1}$ ditolak sehingga dapat disimpulkan variabel Capital Adequacy Ratio (CAR)tidak berpengaruh secara parsial terhadap Return On Assets (ROA).

b. Variabel Non Performing Loan (NPL)sebagai variabel independen menunjukkan hasil statistik uji signifikansi parsial uji $t_{\text {hitung }}=-5,640$ sedangkan $\quad t_{\text {tabel }} 2,446 \quad t_{\text {hitung }}>\quad t_{\text {tabel }}$ dengan nilai signifikansi $0,001<0,05$. Maka dapat diketahui bahwa $\mathrm{Ho}_{2}$ ditolak dan $\mathrm{Ha}_{2}$ diterima sehingga dapat disimpulkan variabel Non Performing Loan (NPL)berpengaruh secara parsial terhadap Return On Assets (ROA).
Uji Signifikansi Simultan (Uji f)

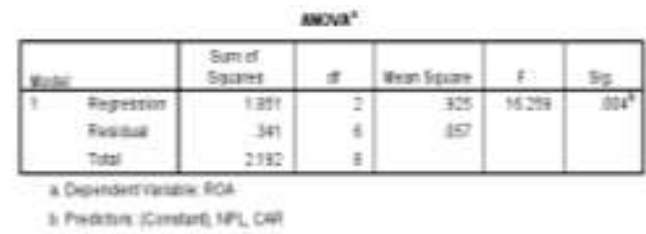

Hasil uji signifikansi simultan (uji f) dapat diketahui bahwa nilai $F_{\text {hitung }}$ adalah 16,529 dan $F_{\text {tabel }} 5,14$ ( $F_{\text {hitung }}>F_{\text {tabel }}$ ) dengan nilai signifikansi $0,004<0,05$ maka bahwa $\mathrm{Ho}_{3}$ ditolak dan $\mathrm{Ha}_{3}$ diterima sehingga dapat disimpulkan bahwa Capital Adequacy Ratio (CAR) dan Non Performing Loan (NPL) berpengaruh pada Return On Assets (ROA).

\section{Analisis Koefisien Determinasi $\left(\mathbf{R}^{\mathbf{2}}\right)$}

Menurut Ghozali (2013:97) koefisien determinasi $\left(\mathrm{R}^{2}\right)$ bertujuan untuk mengukur seberapa jauh kemampuan model dalam menerangkan variasi variabel dependen.

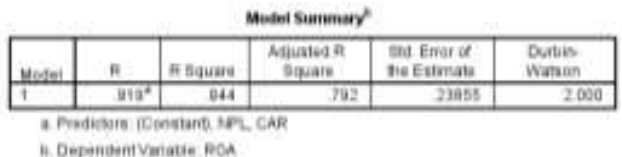

Nilai koefisien determinasi ( $\mathrm{R}$ Square) adalah sebesar 0,844 besarnya nilai tersebut sama dengan $84,40 \%$. Hal ini menunjukkan bahwa Return On Assets (ROA) sebagai variabel terikat (depanden) dipengaruhi oleh Capital Adequacy Ratio (CAR) dan Non Performing Loan (NPL) sebagai variabel bebas (independen) sebesar $84,40 \%$ dan sebesar dan 15,60\% dipengaruhi oleh variabel lain. Nilai $84,40 \%$ menunjukkan model regresi yang baik dan layak.

\section{KESIMPULAN}

Berdasarkan hasil penelitian dan pembahasan yang telah dilakukan 
pembahasan pengaruh Capital Adequacy Ratio (CAR) dan Non Performing Loan (NPL) sebagai variabel independen terhadap Return On Assets (ROA) sebagai variabel dependen pada PT Bank Rakyat Indonesia diperoleh kesimpulan sebagai berikut :

1. Capital Adequacy Ratio (CAR) sebagai variabel independen $\left(\mathrm{X}_{1}\right)$ tidak berpengaruh secara signifikan terhadap Return On Assets (ROA) PT Bank Rakyat Indonesia Tbk. Hal ini dibuktikan dengan hasil perhitungan uji t dengan menggunakan SPSS versi 20 dengan hasil perhitungan statistik uji t yang menunjukkan hasil statistik uji signifikansi parsial uji $t_{\text {hitung }}=$ 1,159 sedangkan $t_{\text {tabel }} 2,446 t_{\text {hitung }}<t_{\text {tabel }}$ dengan nilai signifikansi 0,291 >0,05.

Maka dapat diketahui bahwa $\mathrm{Ho}_{1}$ diterima dan $\mathrm{Ha}_{1}$ ditolak sehingga dapat disimpulkan variabel Capital Adequacy Ratio (CAR)tidak berpengaruh terhadap Return On Assets (ROA).

2. Non Performing Loan (NPL) sebagai variabel independen $\left(\mathrm{X}_{2}\right)$ berpengaruh secara signifikan terhadap Return On Assets (ROA) PT Bank Rakyat Indonesia Tbk. Hal ini dibuktikan dengan hasil perhitungan uji t dengan menggunakan SPSS versi 20 dengan hasil perhitungan menunjukkan hasil statistik uji signifikansi parsial uji $\mathrm{t}_{\text {hitung }}=-5,640$ sedangkan $\mathrm{t}_{\text {tabel }} 2,446$ $t_{\text {hitung }}>t_{\text {tabel }}$ dengan nilai signifikansi $0,001<0,05$. Maka dapat diketahui bahwa $\mathrm{Ho}_{2}$ ditolak dan $\mathrm{Ha}_{2}$ diterima sehingga dapat disimpulkan variabel Non Performing Loan (NPL)berpengaruh terhadap Return On Assets (ROA).
3. Secara simultan Capital Adequacy Ratio (CAR) dan Non Performing Loan (NPL) berpengaruh secara signifikan terhadap Return On Assets (ROA) PT Bank Rakyat Indonesia Tbk. Hal ini dibuktikan dengan hasil perhitungan uji f dengan menggunakan SPSS versi 20 dengan hasil perhitungan statistik uji dapat diketahui bahwa nilai $F_{\text {hitung }}$ adalah 16,529 dan $\mathrm{F}_{\text {tabel }} 5,14\left(\mathrm{~F}_{\text {hitung }}>\mathrm{F}_{\text {tabel }}\right)$ dengan nilai signifikansi $0,004<0,05$ maka bahwa $\mathrm{Ho}_{3}$ ditolak dan $\mathrm{Ha}_{3}$ diterima sehingga dapat disimpulkan bahwa Capital Adequacy Ratio (CAR) dan Non Performing Loan (NPL) berpengaruh pada Return On Assets (ROA) pada PT Bank Rakyat Indonesia Tbk.

\section{DAFTAR PUSTAKA}

Elprido, Ganatha "Pengaruh Capital Adequacy Ratio (CAR) Dan Non Performing Loan (NPL) Terhadap Pertumbuhan Laba Pada PT Bank Cetral Asia Tbk.Periode 20072016", 2017.

Fahmi,Irham "Pengantar Manajemen Keuangan" Ghalia Indonesia, Jakarta, 2011.

Fahmi, Irham "Manajemen Perbankan Konvensional \& Syariah" Mitra Wacana Media, Bekasi, 2015.

Handayani "Pengaruh Capital Adequacy Ratio (CAR) Dan Non Performing Loan (NPL) Terhadap Profitabilitas (ROA) Pada PT Bank Cetral Asia Tbk.Periode 20092013", 2015.

Harahap, Sofyan Safri "Analisis Kritis atas Laporan Keuangan" Raja Grafindo Persada, Jakarta, 2013. 


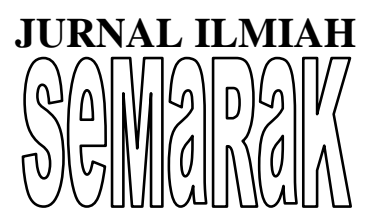

P-ISSN 2615-6849, E-ISSN 2622-3686

Jurnal Semarak,Vol. 3,No.1, Februari 2020, Hal (41- 51)

@Prodi Manajemen Fakultas Ekonomi Universitas Pamulang

Ismail, S “Pengantar Manajemen", Erlangga, Jakarta, 2011.

Ismail, Abdul Ghafar, Kartiko A. Wibowo, Widyanto bin Mislan Cokrohadisumarto. "BMT Praktik dan Kasus". Rajawali Press, 2016.

Kamaludin "Pengaruh Non Performing Loan (NPL)Dan Capital Adequacy Ratio (CAR) Terhadap Profitabilitas Return On Asset (ROA) Pada PT Bank BRI Tbk”, 2017.

Kasmir, "Pengantar Manajemen Keuangan", Kencana, Jakarta, 2009.

Kasmir, “Analisis Laporan Keuangan”, Raja Grafindo, Jakarta, 2012.

Kasmir, "Bank dan lembaga keuangan lainnya",Rajawali Pers, Jakarta, 2013.

Kasmir, "Dasar Dasar Perbankan", Rajawali Pers, Jakarta, 2014.

Apandi, Muhammad Ridwan "Pengaruh Capital Adequacy Ratio (CAR) DanNonPerforming Loan (NPL) Terhadap Profitabilitas (ROA) Studi Pada PT Bank Negara Indonesia Tbk.”, 2017

Purnomo, S., \& Pasaribu, V. L. D. (2019). PERGERAKAN HARGA SAHAM PT ADARO ENERGY TBK (ADRO) PADA PENGUMUMAN DIVIDEN INTERIM TAHUN BUKU 2018. Jurnal Ekonomi Efektif, 2(1).

Pratiwi, Melisa Indah "Pengaruh Capital Adequacy Ratio (CAR) Dan Non PerformingLoan (NPL) Terhadap Profitabilitas (ROA) Di Sektor Perbankan Study Pada PT BNI Tbk. Periode 2007-2015", 2016.
Sucahyowati, H. "Pengantar Manajemen" Wilis, 2017.

Sugiyono, "Metode Penelitian Kuantitatif, Kualitatif dan $R \quad \& \quad D$ ", Alfabeta, Bandung, 2010.

Sugiyono, "Metode Penelitian Kombinasi (Mixed Methods)"Alfabeta, Bandung, 2011.

Sugiyono, "Metode Penelitian Kuantitatif Kualitatif dan Kombinasi" Alfabeta, Bandung, 2013.

Supatmin, S., Sutiman, S., Krisnaldy, K., Lisdawati, L., \& Faisal, F. (2020). PELATIHAN MENGENAI MANAJEMEN PENYUSUNAN PELAPORAN DAN PENGELOLAAN KEUANGAN YANG EFEKTIF DAN EFISIEN POSYANTEK KECAMATAN SETU TANGERANG SELATAN. Abdi Laksana, 1(1).

Sutiman, S. (2019). PENGARUH ROA DAN DAR TERHADAP EPS PADA PT. MANDOM INDONESIA TBK. TAHUN 2007-2017. DISRUPSI BINIS, 1(3).

Timan, S. (2017). ANALISIS SUMBER DAN PENGGUNAAN DANA DALAM UPAYA PENINGKATAN LIKUIDITAS DAN KEMAMPULABAAN PADA PT BANK X (PERSERO). Jurnal Mandiri: Ilmu Pengetahuan, Seni, dan Teknologi, 1(2), 289-310.

Taswan, "Manajemen Perbankan Konsep, Teknik, dan Aplikasi Edisi Kedua", UPP STIM YKPN, Yogyakarta, 2010. 
JURNAL ILMIAH

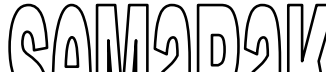
r) 5 (1)
P-ISSN 2615-6849, E-ISSN 2622-3686

Jurnal Semarak,Vol. 3,No.1, Februari 2020, Hal (41- 51)

@Prodi Manajemen Fakultas Ekonomi Universitas Pamulang 